\title{
The Quest for Innovative Strategies to Increase Productivity
}

\author{
Libby V. Morris
}

Published online: 29 June 2011

(C) Springer Science+Business Media, LLC 2011

In this issue of Innovative Higher Education, Adrianna Kezar examines the following question. "What is the best way to achieve broader reach of improved practices in higher education?" At the outset, she notes that policymakers and the general public increasingly expect post-secondary institutions to achieve broad national goals quickly and effectively by the adoption of programs and practices (often funded) that have been "successful" in another place, a practice known as "scale-up." In conclusion, she cautions against the use of simplistic scale-up models, which basically take a "successful" innovation from a local setting and then apply it to other places with little consideration for differences in context.

Following the failure of top-down approaches to bring about desired changes and outcomes, the idea to "scale-up" caught the interest of grantors, policymakers, and educators. However, the history of scale-up innovations in k-12 is not one of success; in fact, Kezar uses the term "dismal record." She elaborates that the adopters need to consider the concepts of depth, sustainability, spread, and ownership in order for scaling up to be effective. For change to be long-lasting, educators must attend to rewards, cultural norms, and capacity. In the end, she concludes that the lessons and practices of social movements and the concepts of mutual adaption are more appropriate for consideration than the practices associated with scaling up if higher education is to achieve broader adoption of change. Kezar's analysis of the expansion of service learning from 200 colleges to over 3000 colleges in less than a decade provides useful insight for administrators considering the adoption and expansion of innovations.

Kezar's article intrigued me as I spend quite a bit of time in meetings and discussions of higher education problems and opportunities at the state and university level. Often the conversation will turn to the internal bureaucratic barriers to change, the lack of funding for innovation, and sometimes the lack of interest by the constituents who must embrace and implement new ideas and practices. Occasionally, participants will point to a successful program or process at a peer or aspirational institution; and then we muse about how that will or will not work here. On the flip side, someone will propose that we have a successful

L. V. Morris $(\bowtie)$

University of Georgia Athens, Athens, GA, USA

e-mail: lvmorris@uga.edu 
and "innovative" program or practice; but our dissemination of the program and practice has been lackluster. At the national or institutional level, change is indeed difficult to bring about; and the long sustained process needed to adapt (or create) a program or process that can take hold and succeed is only for those with the "true grit" or, as we say in professional circles, ....perseverance.

Just as I was reading the Kezar article, the American Council on Education (ACE) issued an article titled "The Innovative University: Changing the DNA of Higher Education" by Eyring and Christensen (2011), based on a forthcoming book. To download the article, go to http:// www.acenet.edu/AM/Template.cfm?Section=Programs_and_Services\&ContentID=40366.

ACE features this article as the first in the series entitled Making Productivity Real: Essential Readings for Campus Leaders." The preface states that higher education must increase student access, enrollment, and attainment (graduation) and that improved productivity is necessary to achieve these goals. These national goals are noted in Kezar's introduction; and they are the guiding force for accrediting bodies, foundations, federal agencies, and public and private institutions. The preface in the ACE article states: "ACE believes that postsecondary education institutions and systems must be open to the implementation of cutting-edge strategies to enhance productivity, with the end goals of expanding capacity, improving teaching and learning, and better serving an increasingly diverse 21 st century student population" (p. iii). The initiative Making Productivity Real is a collaboration between ACE and the Forum for the Future of Higher Education (Educause) with support from the Lumina Foundation and with the aim of creating a national dialogue around the topic of productivity. Needless to say, the economy is also shaping the heightened interest in productivity.

The Eyring and Christensen article provides a succinct overview on the driving forces behind individual and institutional decision-making that makes innovation challenging, yet necessary. The sections of this article include the longstanding college belief that bigger is better, the traditional stance of ignoring "competitive disruption" in the marketplace such as distance technologies, an overview of change by Harvard leaders that led to success and how those are only partially adopted by other universities, the advantage that traditional universities could exhibit with hybrid education, and the overwhelming need for focus on internal challenges and opportunities. In the future, being everything to everyone will be unsustainable in most institutions. In conclusion, the authors cite Lawrence Lowell, president of Harvard from 1909 to 1933, and his observation that Harvard's most persistent tradition is the tradition of change (p.10).

I commend both the Kezar and the Eyring and Christensen articles to you to launch an in depth dialogue on change, productivity, innovation, and quality in your unit, department, or college. Both works are thought-provoking.

\section{Reference}

Eyring, H. J., \& Christensen, C. M. (2011). The innovative university: Changing the DNA of higher education. Making Productivity Real: Essential Readings for Campus Leaders Series: 1. Retrieved from http://www. acenet.edu/AM/Template.cfm?Section=Programs_and_Services\&CONTENTID=40357\&TEMPLATE=/ $\mathrm{CM} /$ ContentDisplay.cfm 